\title{
Remote Sensing and GIS based Approach for Morphometric Analysis of Selected Watersheds in Chiplun Tehsil of Maharashtra, India
}

\author{
B. V. Jawale* and A. P. Bowlekar \\ Dr. Budhajirao Mulik College of Agricultural Engineering and Technology, Mandki-Palvan, \\ Tal. Chiplun 415 641, Dist: Ratnagiri (MH), India \\ *Corresponding author
}

\section{A B S T R A C T}

Geospatial technologies i.e. Remote Sensing (RS) and Geographic Information System (GIS) are found to be very essential tools for

\section{Keywords}

Remote Sensing, GIS, Watershed, Morphometry, Chiplun

\section{Article Info}

\section{Accepted:}

04 March 2020

Available Online:

10 April 2020 geographical and geospatial studies. RS and GIS were adopted for the determination of morphological characteristics of the Chiplun tehsil of Maharashtra, India. It was found that, there were 1362 micro watersheds in Chiplun tehsil covering an area of $1119.95 \mathrm{~km}^{2}$. Several morphometric parameters were computed and analyzed viz. linear aspects such as stream order, stream number, stream length, mean stream length, stream length ratio; areal aspects such as drainage density, stream frequency, drainage texture, elongation ratio, circularity ratio, form factor, constant of channel maintenance; relief aspects such as relief, relief ratio, relative relief, ruggedness number and length of overland flow. It was concluded that, morphometric analysis of a watershed is a quantitative way of describing the characteristics of the surface form of a drainage pattern and provides important information about the region's topography and runoff.

\section{Introduction}

Remote Sensing (RS) means obtaining information about an object, area or phenomenon without coming in direct contact with it whereas, Geographical Information System (GIS) primarily deals with geographic data to be analyzed, manipulated and managed in an organized manner through computers to solve real World problems
(Patra, 2015). RS technique is the convenient method for morphometric analysis as the satellite images providing a synoptic view of a large area and is very useful in the analysis of drainage basin morphometry (Rai et al., 2014). The morphometric characteristics of the basin are fundamental to understand the various hydrological behavior or process (Sarma et al., 2013). Various hydrological phenomena is correlated with the 
physiographic characteristics of a drainage basin such as size, shape, slope of the drainage area, drainage density, size and length of the contributories, etc. (Pande and Moharir, 2015). Detailed morphometric analysis of a basin is a great help in understanding the influence of drainage morphometry on landforms and their characteristics (Sreedevi, 2009). Morphometric and hypsometric analysis is widely used to assess the drainage characteristics of the river basins (Umrikar, 2016).

The fast emerging Spatial Information Technology, RS, GIS and GPS are effective tools to overcome most of the problems of land and water resources planning and management rather than conventional methods of data processing (Rai et al., 2014). Over the past two decades these information has been increasingly derived from the digital representation of topography, generally called as the Digital Elevation Model (DEM). In recent years the automated determination of drainage basin parameter has been shown to be efficient, time saving and ideal application of GIS technology (Sarma et al., 2013). In the present study an attempt has been made to with specified objective to analyze the morphometric characteristics of the major watersheds of Chiplun tehsil of Ratnagiri district of Maharashtra using RS and GIS.

\section{Materials and Methods}

\section{Study area}

As shown in Fig. 1, Chiplun tehsil is located between longitude $73^{0} 19^{\prime} 48^{\prime \prime} \mathrm{E}$ to $73^{\circ} 45^{\prime} \mathrm{E}$ and latitude $17^{0} 37^{\prime} 12^{\prime \prime} \mathrm{N}$ to $17^{0} 13$ ' 12 " $\mathrm{N}$ on western coast of India in southern part of the Ratnagiri district, Maharashtra, India. The total area of Chiplun tehsil is $1119.95 \mathrm{~km}^{2}$. It receives an average annual rainfall of about $3804 \mathrm{~mm}$. The average minimum and maximum temperatures are $7.5^{\circ} \mathrm{C}$ and $38.5^{\circ} \mathrm{C}$, respectively. The relative humidity varies from $55 \%$ to $99 \%$. The soil in the region is highly drainable lateritic and non-lateritic soils (Mandale, 2016).

\section{Watershed delination}

Watershed delineation plays an important role in watershed management (Singh, 2000). ArcGIS 10.3 software is used for the purpose of watershed delineation using CartoDEM data. The shape file generated through watershed delineation of the study area is used for clipping satellite images for further processing.

\section{Morphological characteristics}

The physical properties of the watershed affect the characteristics of runoff and are of great interest in hydrologic analysis. The morphological characteristics such as stream order, drainage density, channel length, channel slope, watershed length and width, topography, geology and or soil characteristics, climate, vegetation and land use are all important to our understanding the physical processes of the watershed (Singh, 2000).

Morphological characterization is the systematic description of watershed geometry. Geometry of drainage basin and its stream channel system required the following measurements (Singh, 2000):

\section{Linear aspect of drainage network}

\section{Areal aspect of drainage basin}

3. Relief aspect of channel network and contributing ground slopes

The morphometric parameters of the watershed, their symbol used and formulae adopted are shown in Table 1. 


\section{Results and Discussion}

It was found that there were 1362 microwatersheds located in Chiplun tehsil derived from DEM, out of which, five microwatersheds were having an area above 50 $\mathrm{km}^{2}$. Fig. 2 shows all the micro-watersheds in the study area. As these are major microwatersheds in Chiplun tehsil, the morphological characteristics of these watersheds were determined. These watersheds had well developed drainage network up to $5^{\text {th }}$ stream order with the total area of $1119.95 \mathrm{~km}^{2}$.

\section{Linear aspects of drainage network}

\section{Stream order (u)}

Application of this ordering procedure through GIS showed that the drainage network of the study area was upto $5^{\text {th }}$ order basin.

\section{Stream number $\left(\mathbf{N}_{\mathrm{u}}\right)$}

From Table 2, it was observed that the total numbers of streams of $1^{\text {st }}, 2^{\text {nd }}, 3^{\text {rd }}, 4^{\text {th }}$ and $5^{\text {th }}$ order for watershed 1 were 145, 32, 8, 2 and 1 , respectively. It was observed that the total number of streams gradually decreased as the stream order increased. Fig. 3, 4, 5, 6 and 7 shows the drainage map of watershed 1, 2, 3, 4 and 5 , respectively.

\section{Bifurcation ratio $\left(\mathbf{R}_{\mathbf{b}}\right)$}

From Table 2, it was observed that the mean bifurcation ratio $\left(\mathrm{R}_{\mathrm{b}}\right)$ for watershed 1 was found to be 3.63. Similarly, the mean bifurcation ratio of watershed 2, 3, 4 and 5 was $3.43,3.55,8.5$ and 3.7 , respectively. The value of mean $R_{b}$ of watershed $1,2,3$ and 5 indicates geological structures do not disturb the drainage pattern. The value of $R_{b}$ was 8.5 for watershed 4 indicates that geologic structures do not exercise a dominant influence on the drainage pattern (Chow, 1964).

\section{Mean stream length $\left(\mathbf{L}_{\mathbf{u}}\right)$}

From Table 2, it was observed that the mean stream length decreases with increase in order of stream. This may be due to the geomorphologic, lithological and structural control and contrast (Strahler, 1964).

\section{Stream length ratio $\left(\mathbf{R}_{\mathbf{L}}\right)$}

From Table 2, it was observed that the average stream length ratio for watersheds 1 was found to be 0.55 . Similarly the average stream length ratio for watersheds $2,3,4$ and 5 was $0.54,0.40,0.68$ and 0.51 , respectively. The stream length ratio has an important relationship with surface flow discharge and erosion stage of basin. It may be controlled by structure and streams having limited length (Sreedevi et al., 2009). Thus, these watersheds are prone to erosion.

\section{Areal aspects of drainage network}

\section{Form factor $\left(\mathbf{R}_{\mathbf{f}}\right)$}

From Table 3, it was observed that the form factor for watershed 1, 2, 3, 4 and 5 were $0.82,0.43,0.44,0.24$ and 0.69 , respectively. The shape of watershed is identified by this ratio. $R_{f}$ values varied from 0.24 to 0.82 . This value in all watersheds indicates that they are elongated to sub-circular in shape. The elongated basin indicates that the basin has a flatter peak of flow. The index of form factor shows the inverse relationship with the square of the axial length and a direct relationship with peak discharge (Horton, 1945). Thus, soil conservation structures need to be constructed as a safeguard against peak floods. 


\section{Circulatory ratio $\left(\mathbf{R}_{\mathbf{c}}\right)$}

From Table 3, it was observed that the circulatory ratio for watersheds $1,2,3,4$ and 5 were $0.41,0.32,0.43,0.29$ and 0.69 , respectively. The circulatory ratio ranged between 0.4 to 0.6 for watershed 1,3 and 5 which indicates strongly elongated and highly permeable homogenous geologic materials as shown in Fig. 2, Fig. 4 and Fig. 6, respectively. The values for watershed 2 and 4 were 0.32 and 0.29 , respectively which indicates the tendency of small drainage basin in homogeneous geologic materials to preserve geometrical similarity as shown in Fig. 3 and Fig. 5, respectively. The ratio is more influenced by length, frequency and gradient of various orders rather than slope conditions and drainage pattern of the basin (Miller, 1953).

\section{Elongation ratio $\left(\mathbf{R}_{\mathrm{e}}\right)$}

From Table 3, it was observed that elongation ratio for watersheds $1,2,3,4$ and 5 were 1.59 , $1.31,1.15,1.03$ and 1.13 , respectively. The value of elongation ratio of 1.59 and 1.31 were observed for watershed 1 and 2, respectively which indicates high infiltration capacity and low run off conditions. The watersheds 3, 4 and 5 had low elongation ratio values of $1.15,1.03$ and 1.13 , respectively, indicates that they are susceptible to high erosion and sedimentation load. Also it indicates strong relief and steep ground slope (Rai et al., 2014).

\section{Drainage Density $\left(\mathrm{D}_{\mathrm{d}}\right)$}

From Table 3, it was observed that the drainage density for watersheds $1,2,3,4$ and 5 were $0.94,1.02,1.01,1.01$ and $1.02 \mathrm{~km}^{-1}$, respectively. The drainage density indicates the closeness of spacing of channels and thus stream channel for whole basin. The drainage density for all 5 watersheds indicates weak and impermeable subsurface materials, good vegetation and high relief (Manjare et al., 2014).

\section{Constant of channel maintenance (C)}

From Table 3, it was observed that the values of constant of channel maintenance for watersheds 1, 2, 3, 4 and 5 were 1.06, 0.98, $0.99,0.99$ and $0.98 \mathrm{~km}^{2} \mathrm{~km}^{-1}$, respectively. All the 5 watersheds had higher values for this parameter which indicates low value of drainage density (Schumn, 1956).

\section{Drainage texture $(T)$}

From Table 3, it was observed that drainage texture for watershed $1,2,3,4$ and 5 were $2.03,1.77,1.96,1.2$ and $1.57 \mathrm{~km}^{-1}$, respectively. This parameter shows the relative spacing of drainage network. Drainage texture less than 2 indicates very coarse, between 2 and 4 as coarse, between 4 and 6 as moderate, between 6 and 8 as fine and above 8 as very fine drainage texture (Smith, 1950). Thus, watershed 1 had coarse texture and watersheds 2, 3, 4 and 5 had very coarse texture.

\section{Relief aspects of drainage network}

\section{Relief (H)}

From Table 4, it was observed that the relief was same for all five watersheds of $0.05 \mathrm{~km}$. Basin relief is an important factor in understanding the denudational characteristics of the basin (Sreedevi et al., 2009).

\section{Maximum relief}

From Table 4, it was observed that maximum relief for watersheds $1,2,3,4$, and 5 were $0.95, \quad 0.05, \quad 0.3, \quad 0.15$ and $0.85 \mathrm{~km}$, respectively. 


\section{Relief ratio $\left(\mathbf{R}_{\mathbf{n}}\right)$}

From Table 4, it was observed that relief ratio for watersheds $1,2,3,4$ and 5 were 0.05 , $0.016,0.05,0.017$ and 0.016 , respectively. High value of relief ratio 0.05 for watersheds 1 and 3 indicates hill regions, high relief and steep slopes. Low values of $0.016,0.017$ and 0.016 for watersheds 2,4 and 5 , respectively indicates valley (Sreedevi et al., 2009).

\section{Relative relief $\left(\mathbf{R}_{\mathrm{hp}}\right)$}

From Table 4, it was observed that the relative relief for watershed $1,2,3,4$ and 5 were $0.054,0.055,0.072,0.082$ and $0.13 \%$, respectively.

\section{Ruggedness number}

From Table 4, it was observed that ruggedness number for watershed 1, 2, 3, 4 and 5 were $0.047,0.051,0.05,0.05$ and 0.051 , respectively. This value of ruggedness number occurs when both variables are large and slope is not only steep but long (Strahler, 1956).

\section{Geometric number}

From Table 4, it was observed that geometric number for watersheds $1,2,3,4$ and 5 were $0.18,0.57,0.54,0.49$ and 0.26 , respectively.

\section{Ground slope}

From Table 4, it was observed that the value of ground slope for watersheds 1, 2, 3, 4 and 5 were $0-26,0-8.9,0-9.2,0-10.3$ and $0-19.3 \%$, respectively. An understanding of slope distribution is essential as a slope map provides data for planning, settlement, mechanization of agriculture, etc. (Sreedevi et al., 2009). Maximum slope of $0-26 \%$ was observed for watershed 1 as shown in Fig. 8 which indicates direction of channel reaching downwards on the ground surface. Also higher slope gradient results in rapid runoff with potential soil loss or erosion (Pande and Moharir, 2015). Slope map for watersheds 2, 3, 4 and 5 are shown in Fig. 9, Fig. 10, Fig. 11 and Fig. 12, respectively.

Table.1 Morphometric parameters

\begin{tabular}{|c|c|c|c|c|}
\hline $\begin{array}{l}\text { Morphometric } \\
\text { Parameters }\end{array}$ & Symbol & Formulae & Particulars & Reference \\
\hline \multicolumn{5}{|c|}{ Linear aspect of drainage network } \\
\hline Stream order & $\mathrm{u}$ & $\begin{array}{l}\text { Hierarchical } \\
\text { Rank }\end{array}$ & $\mathrm{u}=$ stream order & Strahler, 1964 \\
\hline Stream number & $\mathrm{N}_{\mathrm{u}}$ & - & $\begin{array}{l}\mathrm{N}_{\mathrm{u}}=\text { Number of stream of } \\
\text { order } \mathrm{u}\end{array}$ & Strahler, 1964 \\
\hline $\begin{array}{l}\text { Bifurcation } \\
\text { ratio }\end{array}$ & $\mathrm{R}_{\mathrm{b}}$ & $\mathrm{R}_{\mathrm{b}}=\frac{\mathrm{N}_{\mathrm{u}}}{\mathrm{N}_{\mathrm{u}+1}}$ & $\begin{array}{l}\mathrm{R}_{\mathrm{b}}=\text { bifurcation ratio } \\
\mathrm{N}_{\mathrm{u}}=\text { number of streams of } \\
\text { order } \mathrm{u} \\
\mathrm{N}_{\mathrm{u}+1}=\text { number of streams } \\
\text { of order } \mathrm{u}+1\end{array}$ & Schumm, 1956 \\
\hline $\begin{array}{l}\text { Mean stream } \\
\text { length }\end{array}$ & $\overline{\mathrm{L}}_{\mathrm{u}}$ & $\overline{\mathrm{L}}_{\mathrm{u}}=\frac{\sum_{\mathrm{i}=1}^{\mathrm{n}} \mathrm{L}_{\mathrm{u}}}{\mathrm{N}_{\mathrm{u}}}$ & $\begin{array}{l}\bar{L}_{\mathrm{u}}=\text { mean length of } \\
\text { channel of order } u \\
\mathrm{~L}_{\mathrm{u}}=\text { total length of stream } \\
\text { segments of order } \mathrm{u}\end{array}$ & Hortan, 1945 \\
\hline
\end{tabular}




\begin{tabular}{|c|c|c|c|c|}
\hline $\begin{array}{l}\text { Stream length } \\
\text { ratio }\end{array}$ & $\mathrm{R}_{\mathrm{L}}$ & $\mathrm{R}_{\mathrm{L}}=\frac{\overline{\mathrm{L}}_{\mathrm{u}}}{\overline{\mathrm{L}}_{\mathrm{u}-1}}$ & $\begin{array}{l}\bar{L}_{u-1}=\text { mean length of } \\
\text { stream of next lower order }\end{array}$ & Hortan, 1945 \\
\hline \multicolumn{5}{|c|}{ Areal aspect of drainage basin } \\
\hline Form factor & $\mathrm{R}_{\mathrm{f}}$ & $\mathrm{R}_{\mathrm{f}}=\frac{\mathrm{A}_{\mathrm{u}}}{\mathrm{L}_{\mathrm{b}}^{2}}$ & $\begin{array}{l}\mathrm{A}_{\mathrm{u}}=\text { basin area } \\
\mathrm{L}_{\mathrm{b}}=\text { basin length }\end{array}$ & Hortan, 1945 \\
\hline $\begin{array}{l}\text { Circulatory } \\
\text { ratio }\end{array}$ & $\mathrm{R}_{\mathrm{c}}$ & $\mathrm{R}_{\mathrm{C}}=\frac{\mathrm{A}_{\mathrm{U}}}{\mathrm{A}_{\mathrm{C}}}$ & $\mathrm{A}_{\mathrm{C}}=$ area of circle & Miller, 1953 \\
\hline Elongation ratio & $\mathrm{R}_{1}$ & $\mathrm{R}_{1}=\frac{\mathrm{D}_{\mathrm{C}}}{\mathrm{L}_{\mathrm{bm}}}$ & $\begin{array}{l}\mathrm{D}_{\mathrm{c}}=\text { diameter of circle } \\
\mathrm{L}_{\mathrm{bm}}=\text { maximum basin } \\
\text { length }\end{array}$ & Schumm, 1956 \\
\hline $\begin{array}{l}\text { Drainage } \\
\text { density }\end{array}$ & $D_{d}$ & $\mathrm{D}_{\mathrm{d}}=\frac{\mathrm{L}}{\mathrm{A}}$ & $\begin{array}{l}\mathrm{L}=\text { Total length of all } \\
\text { stream segments } \\
\mathrm{A}=\text { watershed area }\end{array}$ & Hortan, 1945 \\
\hline $\begin{array}{l}\text { Constant of } \\
\text { channel } \\
\text { maintenance }\end{array}$ & $\mathrm{C}$ & $\mathrm{C}=\frac{1}{\mathrm{D}_{\mathrm{d}}}$ & $\mathrm{D}_{\mathrm{d}}=$ drainage density & Hortan, 1945 \\
\hline $\begin{array}{l}\text { Stream } \\
\text { frequency }\end{array}$ & $\mathrm{F}$ & $\mathrm{T}=\frac{\mathrm{N}}{P}$ & $\begin{array}{l}\mathrm{N}=\text { Total number of } \\
\text { streams of all order } \\
\mathrm{P}=\text { Basin perimeter }\end{array}$ & Hortan, 1945 \\
\hline $\begin{array}{l}\text { Drainage } \\
\text { texture }\end{array}$ & $\mathrm{T}$ & $\mathrm{R}_{\mathrm{f}}=\frac{\mathrm{A}_{\mathrm{u}}}{\mathrm{L}_{\mathrm{b}}^{2}}$ & $\begin{array}{l}\mathrm{A}_{\mathrm{u}}=\text { basin area } \\
\mathrm{L}_{\mathrm{b}}=\text { basin length }\end{array}$ & Hortan, 1945 \\
\hline \multicolumn{5}{|c|}{ Relief aspect of channel network } \\
\hline Relief & $\mathrm{h}$ & - & $\mathrm{H}=$ relief & Schumn, 1956 \\
\hline Maximum relief & $\mathrm{H}$ & $\mathrm{R}_{\mathrm{n}}=\frac{\mathrm{H}}{\mathrm{L}_{\mathrm{h}}}$ & $\mathrm{L}_{\mathrm{h}}=$ horizontal distance & Schumm, 956 \\
\hline Relief ratio & $\mathrm{R}_{\mathrm{n}}$ & $\mathrm{R}_{\mathrm{hp}}=\frac{\mathrm{H}}{\mathrm{P}} \times 100$ & $\begin{array}{l}\mathrm{H}=\text { basin relief } \\
\mathrm{P}=\text { perimeter of basin }\end{array}$ & Schumn, 1956 \\
\hline Relative relief & $\mathrm{R}_{\mathrm{hp}}$ & $\mathrm{HD}=\mathrm{H} \times \mathrm{D}_{\mathrm{d}}$ & $\begin{array}{l}H=\text { basin relief } \\
D_{d}=\text { drainage density }\end{array}$ & Schumn, 1956 \\
\hline $\begin{array}{l}\text { Ruggedness } \\
\text { number }\end{array}$ & HD & $\mathrm{L}_{\mathrm{g}}=\frac{1}{2 \mathrm{D}_{\mathrm{d}}}$ & $\mathrm{D}_{\mathrm{d}}=$ drainage density & Strahler, 1964 \\
\hline $\begin{array}{l}\text { Geometric } \\
\text { number }\end{array}$ & GN & $\mathrm{R}_{\mathrm{n}}=\frac{\mathrm{H}}{\mathrm{L}_{\mathrm{h}}}$ & $\mathrm{H}=$ relief & Schumn, 1956 \\
\hline $\begin{array}{l}\text { Length of } \\
\text { overland flow }\end{array}$ & $\mathrm{L}_{\mathrm{g}}$ & $\mathrm{R}_{\mathrm{hp}}=\frac{\mathrm{H}}{\mathrm{P}} \times 100$ & $\mathrm{~L}_{\mathrm{h}}=$ horizontal distance & Hortan, 1945 \\
\hline
\end{tabular}


Table.2 Linear aspects of drainage network

\begin{tabular}{|c|c|c|c|c|c|}
\hline $\begin{array}{l}\text { Morphological } \\
\text { characteristics }\end{array}$ & $\begin{array}{c}\text { Watershed } \\
1\end{array}$ & $\begin{array}{c}\text { Watershed } \\
2\end{array}$ & $\begin{array}{c}\text { Watershed } \\
\mathbf{3}\end{array}$ & $\begin{array}{c}\text { Watershed } \\
4\end{array}$ & $\begin{array}{c}\text { Watershed } \\
5\end{array}$ \\
\hline Area $\left(\mathbf{k m}^{2}\right)$ & 280.62 & 205.23 & 162.98 & 83.05 & 82.50 \\
\hline Perimeter (km) & 92.54 & 90.19 & 69.36 & 60.52 & 38.74 \\
\hline $\begin{array}{l}\text { Length of Basin } \\
(\mathbf{k m})\end{array}$ & 18.47 & 21.94 & 19.20 & 18.74 & 10.95 \\
\hline \multicolumn{6}{|c|}{ Stream Order } \\
\hline I & 145 & 122 & 110 & 60 & 46 \\
\hline II & 32 & 27 & 18 & 12 & 10 \\
\hline III & 8 & 7 & 5 & 1 & 4 \\
\hline IV & 2 & 3 & 2 & - & 1 \\
\hline $\mathbf{V}$ & 1 & 1 & 1 & - & - \\
\hline Total & 188 & 160 & 136 & 73 & 61 \\
\hline \multicolumn{6}{|c|}{ Bifurcation Ratio } \\
\hline $\mathbf{R}_{\mathrm{b} 1}$ & 4.53 & 4.52 & 6.11 & 5 & 4.6 \\
\hline $\mathbf{R}_{\mathrm{b} 2}$ & 4 & 3.86 & 3.6 & 12 & 2.5 \\
\hline $\mathbf{R}_{\mathrm{b3}}$ & 4 & 2.33 & 2.5 & - & 4 \\
\hline $\mathbf{R}_{\mathrm{b4}}$ & 2 & 3 & 2 & - & - \\
\hline Average & 3.63 & 3.43 & 3.55 & 8.5 & 3.7 \\
\hline \multicolumn{6}{|c|}{ Stream Length (km) } \\
\hline $\mathbf{L}_{\mathrm{u} 1}$ & 132.73 & 108.32 & 85.55 & 43.77 & 42.28 \\
\hline $\mathbf{L}_{\mathrm{u} 2}$ & 68.47 & 52.55 & 41.54 & 21.55 & 21.58 \\
\hline $\mathbf{L}_{\mathrm{u} 3}$ & 27.78 & 24.00 & 30.23 & 18.49 & 16.22 \\
\hline $\mathbf{L}_{\mathrm{u} 4}$ & 33.44 & 16.61 & 7.26 & - & 4.42 \\
\hline $\mathbf{L}_{\mathrm{u} 5}$ & 2.11 & 8.61 & 1.07 & - & - \\
\hline Total & 264.53 & 210.08 & 165.64 & 83.81 & 84.5 \\
\hline \multicolumn{6}{|c|}{ Mean Stream Length $(\mathrm{km})$} \\
\hline$\overline{\mathrm{L}_{\mathrm{u} 1}}$ & 0.92 & 0.89 & 0.78 & 0.73 & 0.92 \\
\hline$\overline{\mathrm{L}_{\mathrm{u} 2}}$ & 2.14 & 1.95 & 2.31 & 1.80 & 2.16 \\
\hline$\overline{\mathrm{L}_{\mathrm{u} 3}}$ & 3.47 & 3.43 & 6.05 & 18.49 & 4.06 \\
\hline$\overline{\mathrm{L}_{\mathrm{u} 4}}$ & 16.72 & 5.54 & 3.63 & - & 4.42 \\
\hline$\overline{\mathrm{L}_{\mathrm{u} 5}}$ & 2.11 & 8.61 & 1.07 & - & - \\
\hline Total & 25.36 & 20.42 & 13.84 & 21.02 & 11.56 \\
\hline \multicolumn{6}{|c|}{ Stream Length Ratio } \\
\hline $\mathbf{R}_{\mathrm{L} 1}$ & 0.52 & 0.49 & 0.48 & 0.49 & 0.51 \\
\hline $\mathbf{R}_{\mathrm{L} 2}$ & 0.41 & 0.46 & 0.73 & 0.86 & 0.75 \\
\hline $\mathbf{R}_{\mathrm{L} 3}$ & 1.20 & 0.69 & 0.24 & - & 0.27 \\
\hline $\mathbf{R}_{\mathrm{L} 4}$ & 0.06 & 0.52 & 0.15 & - & - \\
\hline Average & 0.55 & 0.54 & 0.40 & 0.68 & 0.51 \\
\hline
\end{tabular}


Table.3 Areal aspects of drainage network

\begin{tabular}{|c|c|c|c|c|c|}
\hline Areal Aspects & Watershed 1 & Watershed 2 & Watershed 3 & Watershed 4 & Watershed 5 \\
\hline Basin Area $\left(\mathrm{km}^{2}\right)$ & 280.62 & 205.23 & 162.98 & 83.05 & 82.50 \\
\hline Form Factor & 0.82 & 0.43 & 0.44 & 0.24 & 0.69 \\
\hline Circulatory Ratio & 0.41 & 0.32 & 0.43 & 0.29 & 0.69 \\
\hline Elongation Ratio & 1.59 & 1.31 & 1.15 & 1.03 & 1.13 \\
\hline $\begin{array}{c}\text { Drainage Density } \\
\left(\mathrm{km}^{-1}\right)\end{array}$ & 0.94 & 1.02 & 1.01 & 1.01 & 1.02 \\
\hline $\begin{array}{l}\text { Constant of Channel } \\
\text { Maintenance }\left(\mathrm{km}^{2} \mathrm{~km}^{-1}\right)\end{array}$ & 1.06 & 0.98 & 0.99 & 0.99 & 0.98 \\
\hline $\begin{array}{c}\text { Drainage Texture } \\
\left(\mathrm{km}^{-1}\right)\end{array}$ & 2.03 & 1.77 & 1.96 & 1.2 & 1.57 \\
\hline
\end{tabular}

Table.4 Relief aspects of drainage network

\begin{tabular}{|l|c|c|c|c|c|}
\hline \multicolumn{1}{|c|}{ Relief Aspects } & Watershed 1 & Watershed 2 & Watershed 3 & Watershed 4 & Watershed 5 \\
\hline Relief (km) & 0.05 & 0.05 & 0.05 & 0.05 & 0.05 \\
\hline $\begin{array}{l}\text { Maximum } \\
\text { Relief (km) }\end{array}$ & 0.95 & 0.05 & 0.3 & 0.15 & 0.85 \\
\hline Relief Ratio & 0.05 & 0.016 & 0.05 & 0.017 & 0.016 \\
\hline $\begin{array}{l}\text { Relative Relief } \\
(\%)\end{array}$ & 0.054 & 0.055 & 0.072 & 0.082 & 0.13 \\
\hline $\begin{array}{l}\text { Ruggedness } \\
\text { number }\end{array}$ & 0.047 & 0.051 & 0.05 & 0.05 & 0.051 \\
\hline $\begin{array}{l}\text { Geometric } \\
\text { number }\end{array}$ & 0.18 & 0.57 & 0.54 & 0.49 & 0.26 \\
\hline $\begin{array}{l}\text { Ground Slope } \\
\text { (\%) }\end{array}$ & $0-26$ & $0-8.9$ & $0-9.2$ & $0-10.3$ & $0-19.3$ \\
\hline $\begin{array}{l}\text { Length of } \\
\text { overland flow } \\
\text { (km) }\end{array}$ & 0.53 & 0.49 & 0.49 & 0.49 & 0.49 \\
\hline
\end{tabular}


Fig.1 Location map of the study area

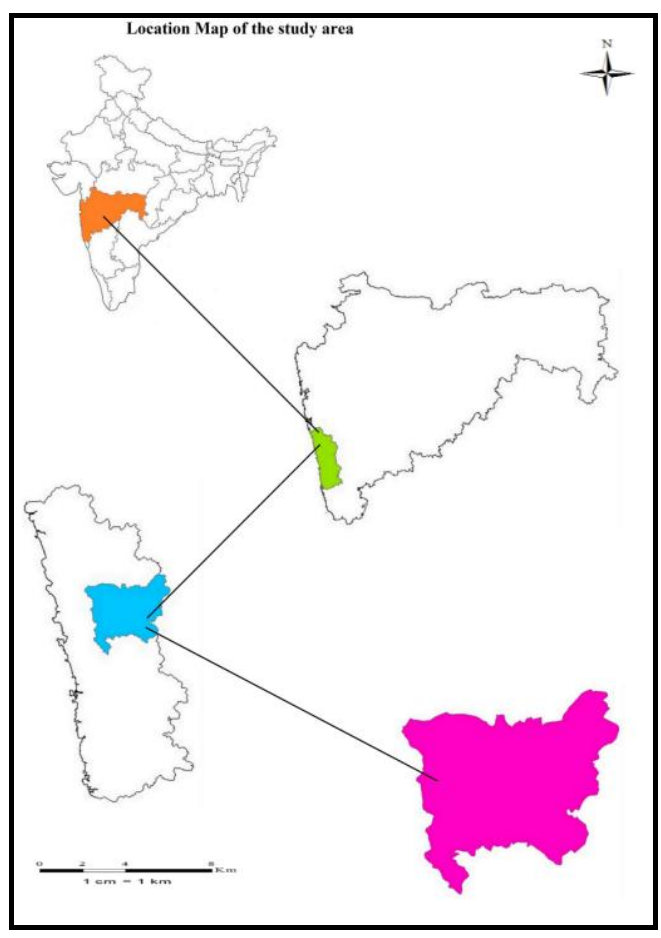

Fig.2 Micro-watersheds in Chiplun Tehsil

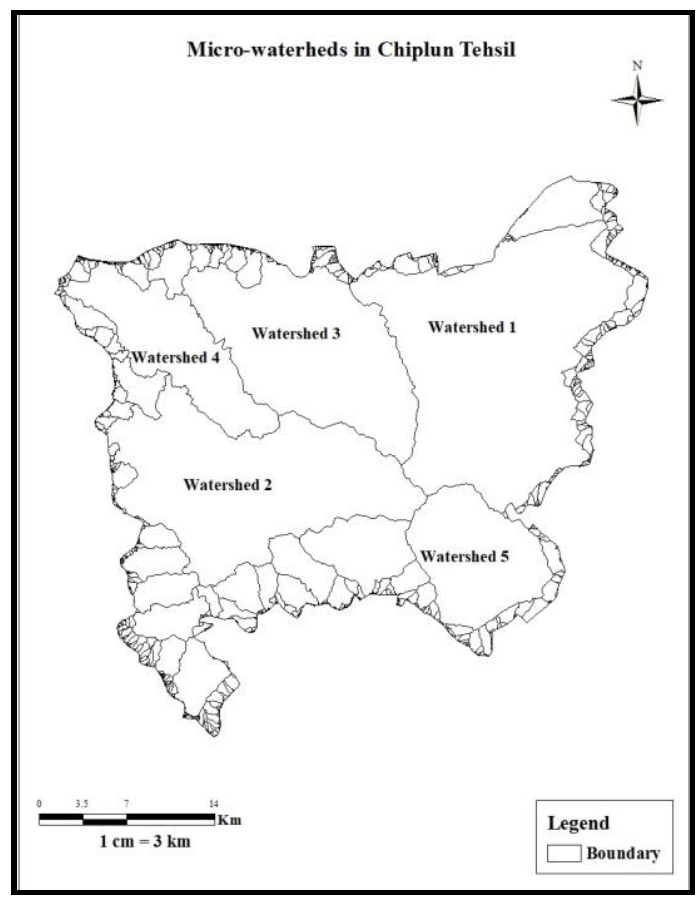


Fig.3 Drainage Map - Watershed 1

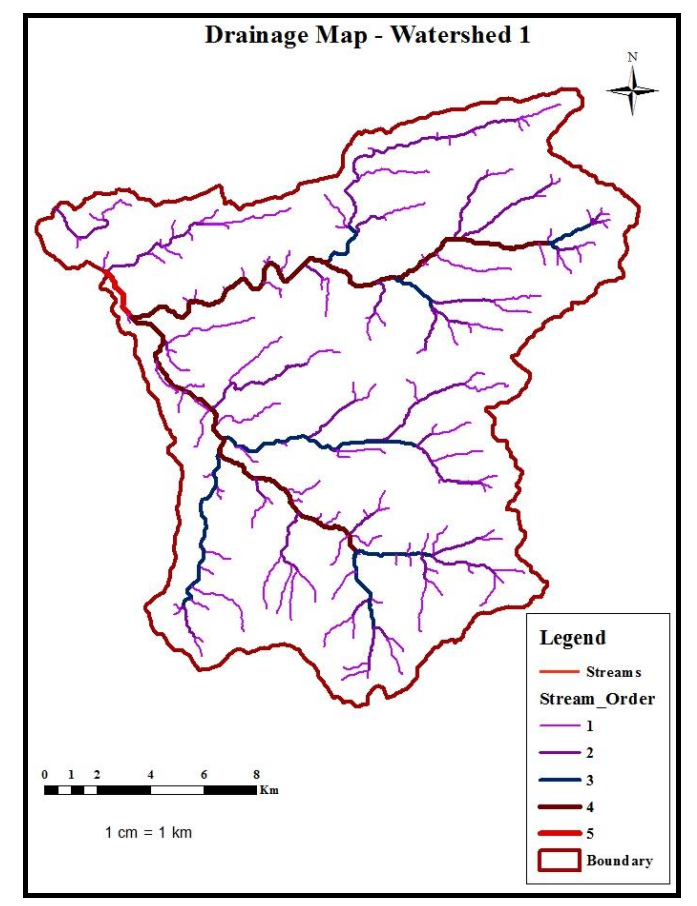

Fig.4 Drainage Map - Watershed 2

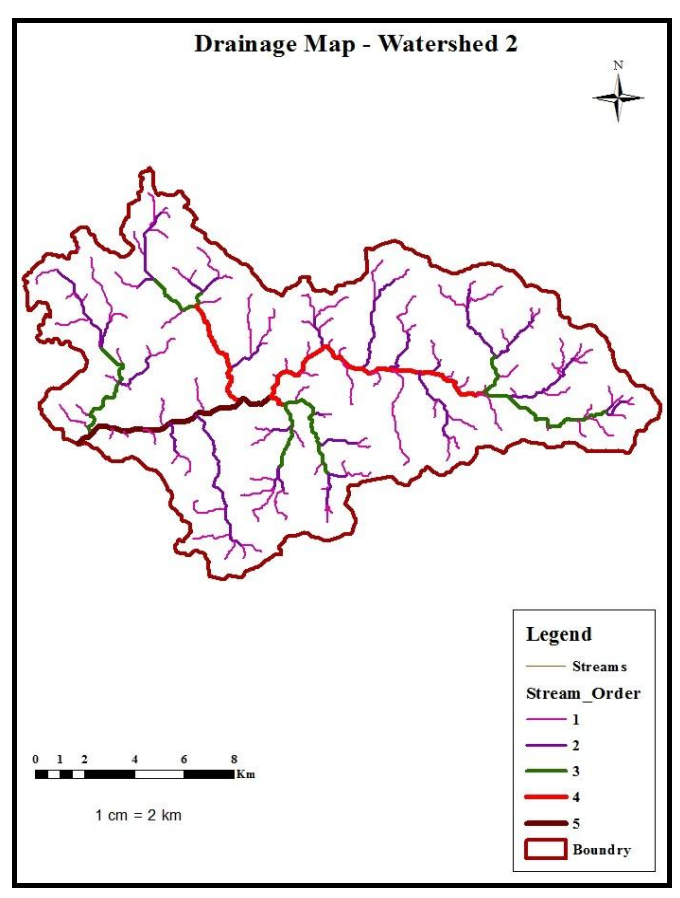

Fig.5 Drainage Map - Watershed 3

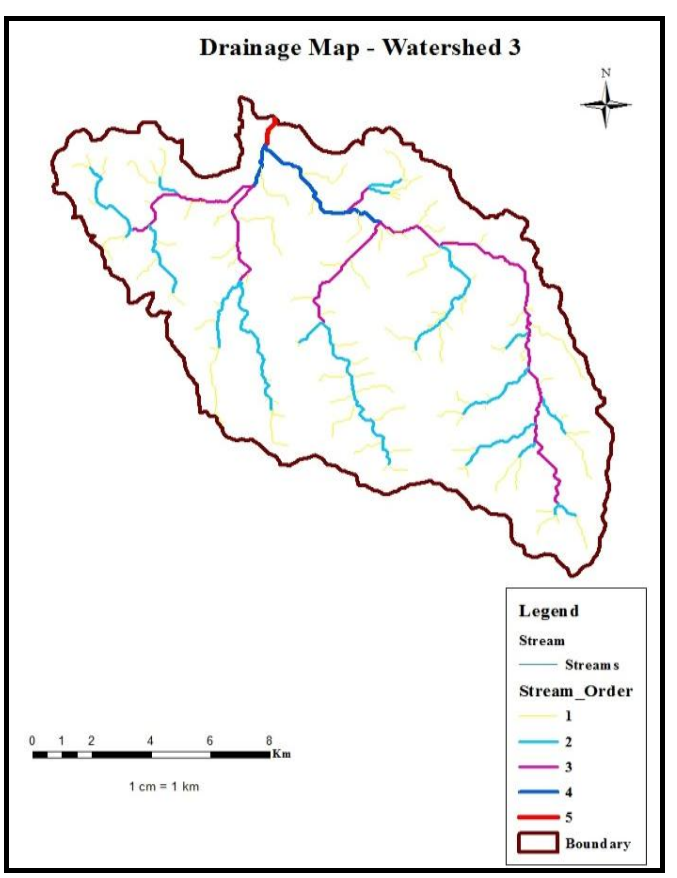


Fig.6 Drainage Map - Watershed 4

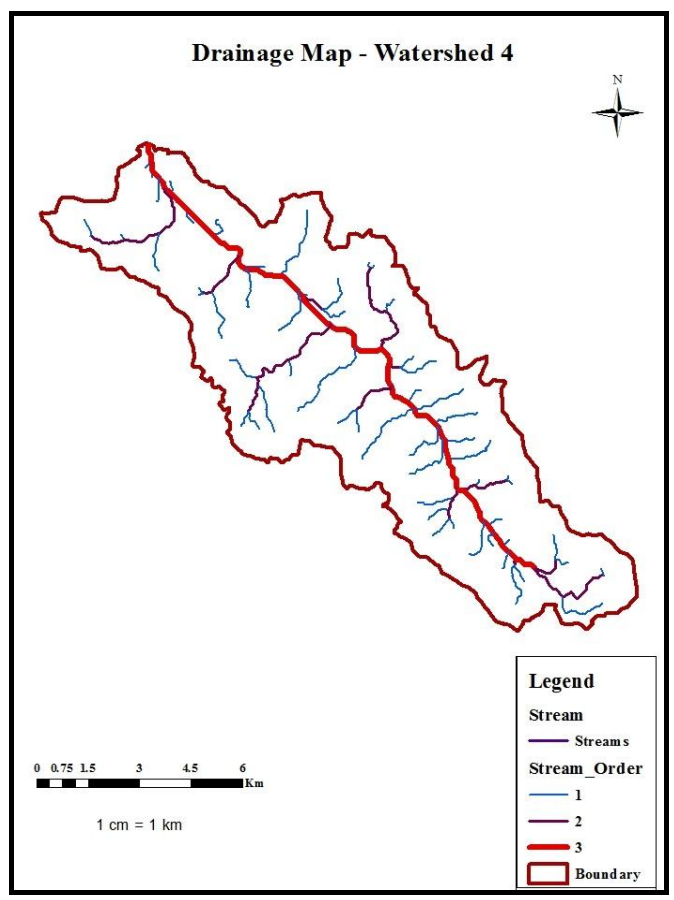

Fig.7 Drainage Map - Watershed 5

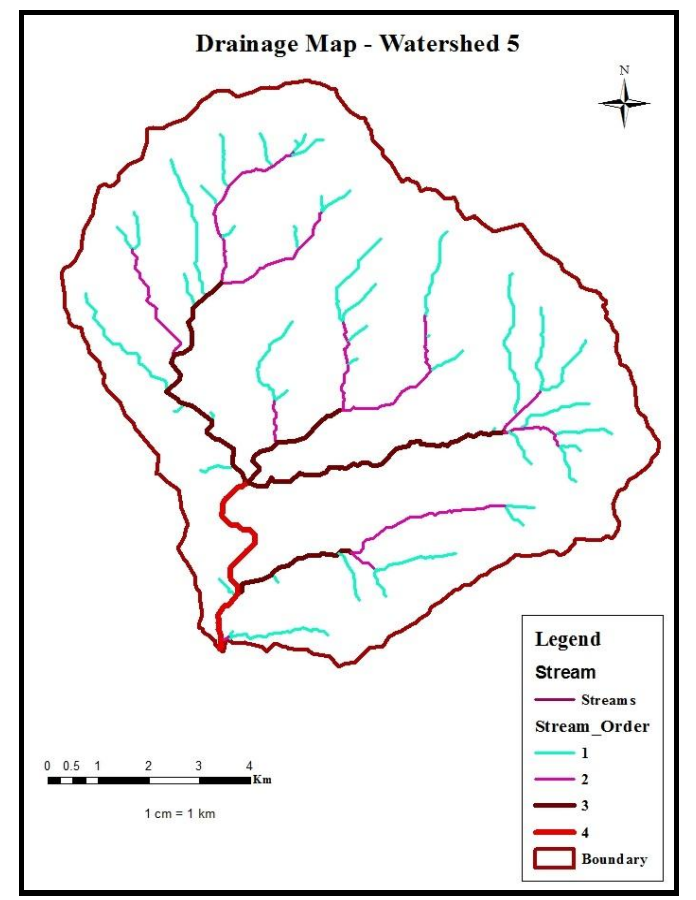

Fig.8 Slope Map - Watershed 1

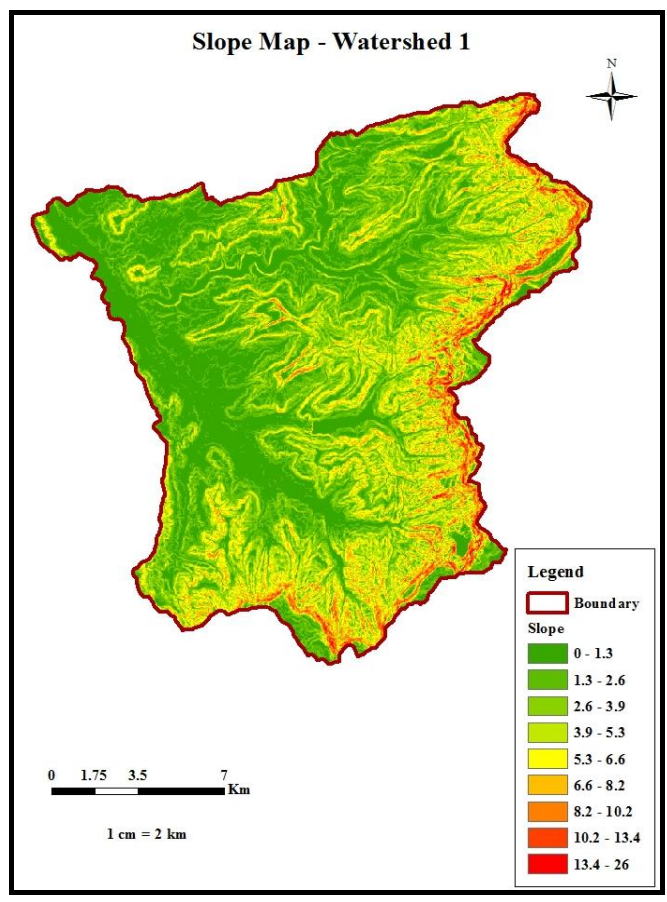


Fig.9 Slope Map - Watershed 2

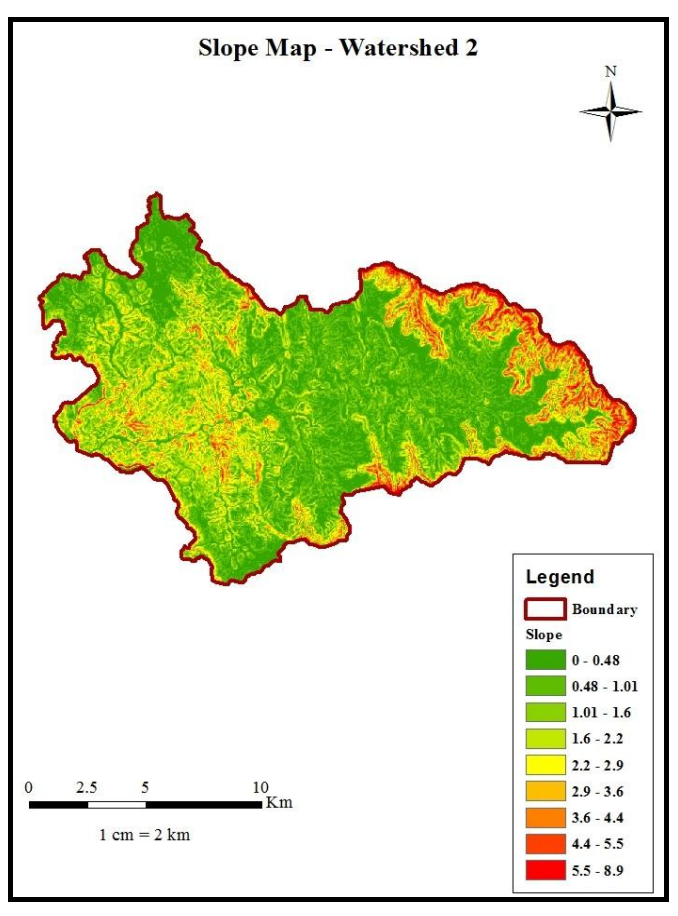

Fig.11 Slope Map - Watershed 4

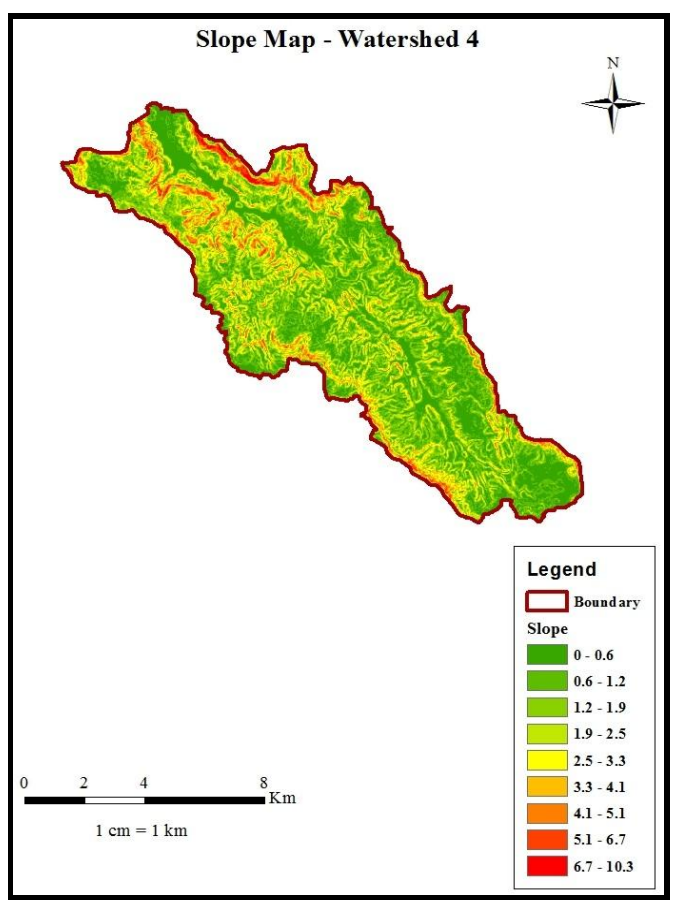

Fig.10 Slope Map - Watershed 3

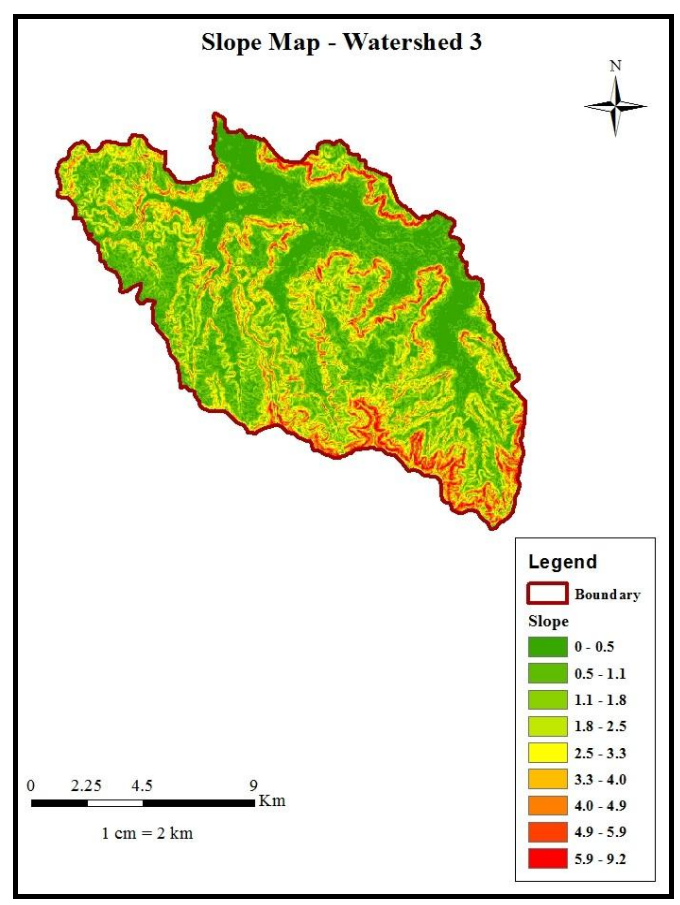

Fig.12 Slope Map - Watershed 5

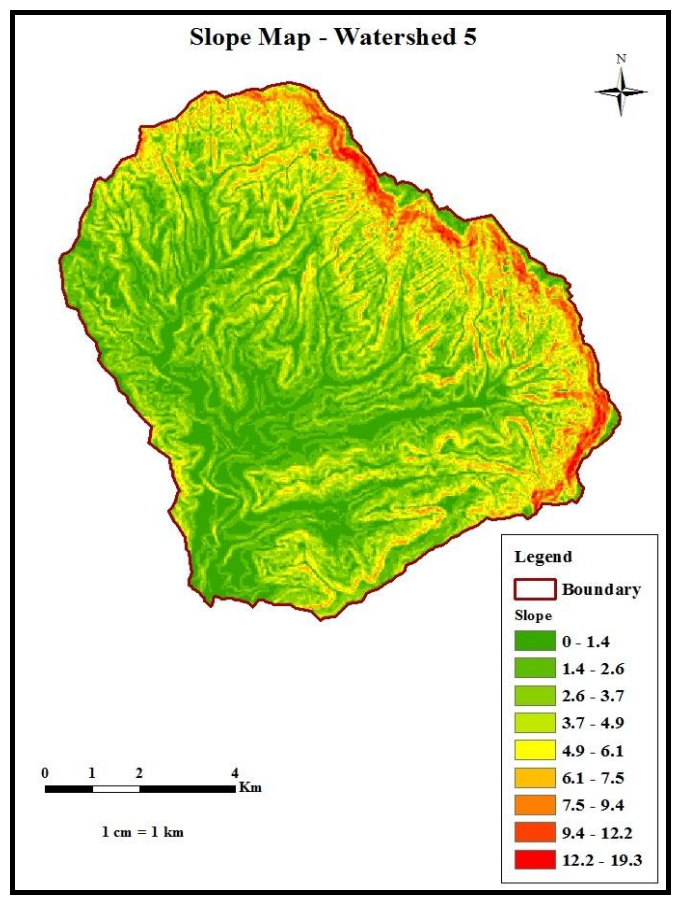




\section{Length of overland flow $\left(\mathrm{L}_{\mathrm{g}}\right)$}

From Table 4, it was observed that the length of overland flow for watersheds $1,2,3,4$ and 5 were $0.53,0.49,0.49,0.49$ and $0.49 \mathrm{~km}$, respectively. Length of overland flow is one of the most important morphometric variables which affect the hydrological and topographic development of drainage network (Kumar, 2013). The high values for this parameter indicates high surface runoff (Manjare et al., 2014).

In conclusions, morphometric analysis of a watershed is a quantitative way of describing the characteristics of the surface form of a drainage pattern and provides important information about the region's topography and runoff. Higher value of bifurcation ratio indicated the watershed had elongated shape and low value indicated the circular shape. The variations in stream length ratio in the study area are due to variations in slope and topography. Form factor in all watersheds indicated that they were elongated to subcircular in shape. The circulatory ratio ranged from 0.4 to 0.6 which indicated strongly elongated and highly permeable homogenous geologic materials. The circulatory ratio less than 0.4 indicated the tendency of small drainage basin in homogeneous geological material to preserve geometrical similarities. The high value of elongation ratio indicated high infiltration capacity and low runoff conditions whereas low elongation ratio values indicated that they were susceptible to high erosion and sedimentation load. Low value of drainage density indicated low permeability, moderate to steep slope and high surface runoff. It was observed that the relief was same for all five watersheds of 0.05 $\mathrm{km}$. High value of relief ratio indicated hill regions, high relief and steep slopes whereas low values indicated valley. The high values of length of overland flow indicated high surface runoff and low values had low surface runoff.

\section{Acknowledgement}

The authors are thankful to Dr. Budhajirao Mulik College of Agricultural Engineering and Technology Mandki - Palvan, Affiliated to Dr. Balasaheb Sawant Konkan Krishi Vidyapeeth, Dapoli.

\section{References}

Chow, V. T., 1964. Handbook of Applied Hydrology. McGraw-Hill, New York: 14-18.

Horton, R. E. 1945. Erosional Development of Streams and their Drainage Density: Hydro Physical Approach to Quantitative Geomorphology. Bulletin of Geological Society of America. 56: 275-370.

Kumar, N. 2013. Morphometric Analysis of River Catchments Using Remote Sensing and GIS in case study of the Sukri River, Rajasthan. International Journal of Scientific and Research Publications. 3: 1-6.

Mandale, V. P. 2016. Trend Analysis of Rainfall in Konkan Region of Maharashtra. Unpublished M. Tech. (Agril. Engg.) Thesis, College of Agricultural Engineering and Technology, Dr. Balasaheb Sawant Konkan Krishi Vidyapeeth, Dapoli, 14.

Manjare, B. S., Padhye M. A. and Girhe S. S. 2014. Morphometric Analysis of Lower Wardha River Sub Basin of Maharashtra, India Using ASTER DEM Data and GIS. Esri India User Conference, 1-13.

Miller, V. C. 1953. A Quantitative Geomorphology Study of Drainage Basin Characteristics in the Clinch Mountain Area, Virginia and Tennessee. Department of Geology, Columbia, Technical Report. 3.

Pande, C. B. and Moharir K. 2015. GIS Based Quantitative Morphometric Analysis and its Consequences in Case Study 
from Shanur River Basin, Maharashtra India. Application of Water Science, 861-871.

Patra, P. 2015. Remote Sensing and Geographical Information System. The Association for Geographical Studies, $1-28$.

Rai, P., Mohan K., Mishra S., Ahmad A. and Mishra V. N. 2014. A GIS-Based Approach in Drainage Morphometric Analysis of Kanhar River Basin, India. Application of Water Science, 217-232.

Sarma, P., Sarmah K., Chetri P. K. and Sarkar A. 2013. Geospatial Study on Morphometric Characterization of Umtrew River Basin of Meghalaya, India. International Journal of Water Resources and Environmental Engineering. 5(8): 489-498.

Schumm, S. A. 1956. Evolution of Drainage Systems and Slopes in Badlands at Perth Amboy, New Jersey. Bulletin of Geological Society of America. 67: 597-646.

Singh, R. V. 2000. Watershed Planning and
Management. Yash Publication. 50-51.

Singh, S. and Singh, M. C. 1997. Morphometric analysis of Kanhar river basin. National Geographical Journal of India. 43 (1): 31-43.

Smith, G. H. 1939. The Morphometry of Ohio: The Average Slope of the Land. Annals of the American Association of the Geographers. 29: 94.

Sreedevi, P. D., Owais S., Khan H. H. and Ahmed S. 2009. Morphometric Analysis of a Watershed of South India Using SRTM data and GIS. Journal Geological Society of India. Pp. 543552.

Strahler, A. N. 1964. Quantitative Geomorphology of Drainage Basins and Channel Networks. In: V.T. Chow (Ed.), Handbook of Applied Hydrology. McGraw-Hill, New York. 39-76.

Umrikar, B. N. 2016. Morphometric Analysis of Andhale Watershed, Taluka Mulshi, District Pune, India. Applied Water Science. 2231-2243.

\section{How to cite this article:}

Jawale, B. V. and Bowlekar, A. P. 2020. Remote Sensing and GIS based Approach for Morphometric Analysis of Selected Watersheds in Chiplun Tehsil of Maharashtra. Int.J.Curr.Microbiol.App.Sci. 9(04): 70-83. doi: https://doi.org/10.20546/ijcmas.2020.904.010 